Studia Anglica Posnaniensia 52(2), 2017

doi: 10.1515/stap-2017-0010

\title{
BAD BOYS MEET THE SWAN OF AVON: A RE-VISIONING OF HAMLET IN SONS OF ANARCHY
}

\author{
KATARZYNA BURZYŃSKA*
}

Faculty of English, Adam Mickiewicz University in Poznań

\begin{abstract}
This article investigates the intersections between Shakespeare's Hamlet and a popular TV series Sons of Anarchy (SOA), loosely based on the Shakespearean original. The crime drama series revolves around an outlaw motorcycle club that literally "rules" a fictional town in California like an old royal family with its own brutal dynastic power squabbles and dark family secrets. The club is governed by an unscrupulous President Clay and an equally violent, though more conflicted, Vice President Jax Teller, the son of the late President, who had died in mysterious circumstances. In the article I argue that the popularity of the series lies not in its graphic scenes of violence, over-the-top Harley chases, and sex intrigues, but rather in its Shakespearean and Renaissance structure. SOA, dubbed as "Hamlet on Harleys"1, is an appropriation rather than an adaptation of Shakespeare's tragedy, which makes it a truly transmedial phenomenon. The article investigates a fascinating blend of seemingly marginal elements of modern American culture and the canonical British tragedy. It also addresses the connections between the lifestyles of the so called outlaw MC clubs and the early modern family structure as presented in Hamlet, focusing on the issues of power and gender relations.
\end{abstract}

Keywords: Hamlet; Sons of Anarchy; appropriation; adaptation; early modern family.

Cesar L. Barber has noted once that "Shakespeare's art is distinguished by the intensity of its investment in the human family" (Barber 1980: 188). Yet, Shakespeare's Hamlet has predominantly been interpreted as an intense exploration of the individual's tormented psyche. Bradley, following Schlegel

* Department of Studies in Culture, Faculty of English, Adam Mickiewicz University, al. Niepodległości 4, 61-874, Poznań, Poland, e-mail: kburzynska@wa.amu.edu.pl.

1 Moody, Mike. 2012. TV Review: Sons of Anarchy 5.2. "Authority Vested", see http://birthmoviesdeath.com/2012/09/19/tv-review-sons-of-anarchy-5.4-authority-vested (accessed on 10 December 2015). 
and Coleridge, refers to the play as "the tragedy of reflection" (Bradley 1992: 86-87). However, it is important to remember that Hamlet's "deep and complex inwardness" has become a key interpretative trait only since the $19^{\text {th }}$ century (de Grazia 2007: 1). Before 1800 the play had been mostly seen as a story of dispossession, in which the patrilineal order is broken and the only son deprived of his land and heritage. As Margreta de Grazia aptly points out:

\begin{abstract}
[t]he promise of the patronymic is broken: Prince Hamlet does not become King Hamlet: Hamlet II does not step into the place of Hamlet I. The kingdom does not pass to the (adult and capable) son of the dead king. This is a remarkable turn of events. In a hereditary monarchy like England's, it would be unthinkable. Yet the critical tradition has mainly ignored the upset, as if dispossession were of no consequence.
\end{abstract}

(de Grazia 2007: 1-2)²

In her argument the play's central theme is the passing on and possession of land, while Hamlet's irregular behaviour stems from his dispossession. The dispossession itself originates in the breaking of the family structure. So it needs to be highlighted that Hamlet's frustrations, dilemmas, and reflections originate in his dysfunctional family that becomes not only a background to his reflection but also a constant stumbling block to his action. On top of the injury of the dispossession, it is also the sorrow after the death of his father, the revulsion at disloyalty of the mother, and the unwillingness to accept an uncle in the role of a father that characterize him at the opening of the play. "A little more than kin, and less than kind" retorts Hamlet to Claudius when the latter calls him both "cousin" and "son" (Hamlet, 1.2.64-65). It is not at all surprising, then, that the very first sentence uttered by Hamlet in the play refers to the family. If "[s]omething is rotten in the state of Denmark" it is Hamlet's family (Hamlet, 1.4.90). After all, it is fratricide as much as regicide that needs to be avenged. Hamlet's revenge has both a political and a personal dimension, in which it is the fractured family that requires mending. Lynda Boose writes: "Shakespeare's dramas consistently explore affective family dynamics with an intensity that justifies the growing

2 Margreta de Grazia in her seminal book Hamlet without Hamlet successfully deconstructs the long tradition of seeing Hamlet as a "play of reflection". She also points out the dangers of cutting Hamlet out of his family context when she says: "[a]s Hamlet's dispossession has been ignored so, too, has Hamlet's investment in land. The connection between character and plot has thereby disappeared: the play has been seen as a mere pretext for the main character, quite literally so when it is assumed that the play's structure derived from an earlier revenge play, the hypothetical Ur-Hamlet, while Hamlet's character issued purely from Shakespeare's creative imagination. Scholarship has been content to treat the plot as inert backdrop to the main character who can readily leave it behind to wander into other and later works, no strings attached" (de Grazia 2007: 3). In this sense, the paper follows de Grazia's rationale in focusing on the family context, rather than only Hamlet's psyche. 
inference among Shakespearean scholars that the plays may be primarily 'about' family relations and only secondarily about the macrocosm of the body politic" (Boose 1982: 325). This inference could also be true for the tragedy of Hamlet. It very often is for modern adaptations of the play. Oedipal overtones in Lawrence Olivier's adaptation or Franco Zeffirelli's incest implications between Hamlet and Gertrude make sense in the family rather than political context. In such light one should investigate Sons of Anarchy, a very popular American TV series and an appropriation of Shakespeare's Hamlet. Thus, the aim of this paper is two-fold; it compares and contrasts Shakespeare's Hamlet and Sons of Anarchy in the context of the early modern family models as well as investigates the cultural ramifications of the transmedial nature of the two versions. Though Sons of Anarchy is a popular series set at the backdrop of a very modern reality it follows a patriarchal family model that clearly dates back to the early modern family structure, whereas the generic and medial transition has some crucial consequences for the presentation of the family context.

Sons of Anarchy is a very loose adaptation or rather an appropriation of Hamlet, set in modern day California ${ }^{3}$. SAMCRO (Sons of Anarchy Motorcycle Club Redwood Original) is an outlaw motorcycle club headed by Clay (modelled on Claudius), the President of the Club and its Vice-President Jax/Jackson Teller (Hamlet), the step-son of the late President, John Teller (The Old Hamlet) who had been a founder of the club and husband to Gemma (Gertrude). All the physical manifestations of the so called "one-percenter" biker culture ${ }^{4}$ are meticulously rendered in the series, to the extent that four actors playing gang

3 In classifying SOA as an appropriation I am following Julie Sanders' definition from her book Adaptation and appropriation (2006).

$4 \quad$ The term "one-percenter" goes back to the events that took place on the $4^{\text {th }}$ of July 1947 in a small Californian town of Hollister, when a registered American Motorcycle Association event got out of control and resulted in wild motorcycle races through the town and some arrests for indecent behaviour. Some newspapers and magazines like Life and The San Francisco Chronicle released articles with graphic content that caused public outrage at the behaviour of the bikers. As Dulaney writes: "The Life story caused something of a tumult around the country (Yates), and some authors have asserted that the AMA subsequently released a press statement disclaiming involvement in the Hollister event, stating that $99 \%$ of motorcyclists are good, decent, law-abiding citizens, and that the AMA's ranks of motorcycle clubs were not involved in the debacle (e.g., Reynolds, Thompson). However, the American Motorcyclist Association has no record of ever releasing such as statement Tom Lindsay, the AMA's Public Information Director, states "We [the American Motorcyclist Association] acknowledge that the term 'one-percenter' has long been (and likely will continue to be) attributed to the American Motorcyclist Association, but we've been unable to attribute its original use to an AMA official or published statement - so it's apocryphal" (Dulaney 2005). So the term "one-percenter" refers to outlaw (not registered by AMA) motorcycle clubs that openly acknowledge their criminal affiliation. For more information on outlaw and one-percenter biker culture see National Gang Report 2015 https://www.fbi.gov/file-repository/national-gang-report-2015.pdf. 
members in the series turn out to be actual members of the Hells Angels Motorcycle Club in real life (Wikipedia). Quite perversely, an outlaw motorcycle club, in spite of being a twentieth-century seemingly marginal construct of American culture, resembles a late-sixteenth or early seventeenth century household. A motorcycle gang is a patriarchal, primogenital, and highly hierarchical structure based on the values of exclusively masculine brotherhood and utmost loyalty to the club. Bikers usually ride Harley Davidson bikes and are known for their special dress code, which is a leather waistcoat known as the cut, adorned by a couple of badges with the name of the club, its logo, possibly its motto, the location of the club, and the rank of the member in the clubs' hierarchy. In this sense such clubs function similarly to old aristocratic families based on feudal relations with their banners, banner men, liege lords etc. This similarity seems to be a key element approximating Sons of Anarchy and Hamlet.

Though the $S O A$ writers frequently and radically depart from the main plot of Hamlet they seem to be always faithful to the central tension of Shakespeare's play. However, because of the departures from the original, the series is still more of an appropriation rather than an adaptation. As Julie Sanders writes, an adaptation of Hamlet "although clearly reinterpreted by the collaborative efforts of director, scriptwriter, actors, and the generic demands of the movement from stage drama to film, remains ostensibly Hamlet, a specific version, albeit achieved in alternative temporal and generic modes, of that seminal cultural text" (Sanders 2006: 26). Sons of Anarchy, along with a different title, also introduce a plethora of extra characters who have no textual equivalents in Shakespeare's original and numerous subplots to fill in the seven seasons the entire series lasts. What is more, they speak modern-day American slang rather than the English of the Swan of Avon. In all this the authors clearly signal "a more decisive journey away from the informing source into a wholly new cultural product and domain" (Sanders 2006: 26). What one eventually gets is a product of popular and mass culture, rather than a highbrow feast for the senses. Until recently the commodification of Shakespeare for the needs of mass culture produced a sense of uneasiness or reluctance. As Douglas Lanier writes: "Shakespeare symbolizes high art in general, the distinction between 'Shakespeare' and 'popular culture' epitomizes one of the great divides in the culture of the last century, the division between highbrow and lowbrow" (Lanier 2002: 3). Yet the positioning of Shakespeare as a bard of high culture is by no means natural. Shakespeare himself was a representative of popular culture and only in the course of history has become "the Bard of high culture" (Henderson 2007: 6). His career as much as his works demonstrate the elusiveness of the stark boundaries between high- and lowbrow culture. So the appropriation of the canonical Shakespearean play for the purposes of serialization in Sons of Anarchy comes nowadays as no surprise. Sons of 
Anarchy might be called by some "Schlockspeare", to use Richard Burt's quaint term for trashy or kitsch versions of Shakespeare's plays (Burt 2002: 3). ${ }^{5}$ However, there is no denying that SOA heavily draw on their Shakespearean original both on the level of ideas as well as text. ${ }^{6}$ As Sanders writes: "[a]daptation and appropriation are dependent on the literary canon for the provision of a shared body of storylines, themes, characters, and ideas upon which their creative variations can be made" (Sanders 2006: 45). In Sons of Anarchy it is the main interpretative axis that remains Shakespearean. Despite the generic shift from a tragedy to a TV crime drama as well as a media transition from stage to silver screen, the series maintains the basic connection with Shakespeare's original subject matter, namely the focus on the skewed power dynamics within the family.

According to Lawrence Stone, between 1500 to 1700 the so called "open lineage families" gradually declined in favour of the restricted patriarchal nuclear family, in which "the importance of the nuclear core increased, not as a unit of habitation but as a state of mind" (Stone 1977: 125). In this sense

$5 \quad$ As Richard Burt writes: "Shakespeare's relationship to mass media has been interpreted one of two ways, either as the democratization of high culture through low media, Orson Welles being a central figure in this regard, or as the dumbing down and debasement of Shakespeare for the masses" (Burt 2002: 3). It seems that both of these stances might actually be used in the context of $S O A$, as on the one hand it uses Hamlet as its main plot axis, but on the other it trivializes and flattens the moral dilemmas encapsulated in the play.

6 Wikipedia article on Sons of Anarchy (section: "Shakespearean influence") enumerates all direct references or allusions to Shakespearean text, e.g., it provides a whole list of all episode titles that are quotations from Shakespeare's Hamlet (https://en.wikipedia.org/ wiki/Sons_of_Anarchy\#Shakespearean_influence).

$7 \quad$ Stone's book The Family, sex and marriage in England 1500-1800 (1977) is now a classic source of knowledge on the early modern family. However, it is worth remembering that when it was originally published it received a lot of criticism for its apparent overgeneralization of the historical process and selective analysis of source texts. The book was criticized, among many, by Alan Macfarlane. Macfarlane believed that the development of individualism, high social and geographical mobility long predated the English Renaissance, so he was against Stone's neat categorization of family types into open lineage families (1450-1630), restricted patriarchal nuclear families (1550-1700), and closed domesticated nuclear families (1640-1800). Having investigated numerous source texts, he writes: "[t]here is no hint that the individual, family and farm were blended. England appears ... to be a society with very high geographical and social mobility, high age at marriage, little emphasis on the local community" (Macfarlane 1978: 257). Even within rural areas the kinship system reflected "a highly mobile, individualistic system" (Macfarlane 1978: 260). Stone is also rejected as a fully reliable source by Bruce W. Young, the author of Family in the age of Shakespeare, who writes: "[a]nother writer, Lawrence Stone, has been especially influential on Shakespearean criticism even though most historians consider his work on English family life deeply flawed" (Young 2008: xi). In such light, it seems reasonable to write against Stone's ideas. Shakespeare's plays seem to demonstrate an intense tension between ideals of distance and control in family life and practices that more than often capture emotional intensity that escapes accepted standards. 
Shakespeare's plays document the moment of transition and, consequently, communicate the anxieties and fears surrounding the development of the modern family as we understand it today. For modern audiences and readers of Shakespeare certain family circumstances in which his characters find themselves are difficult to comprehend. Yet, the passions and moral dilemmas are often easily identifiable. So, in a way, Hamlet's family is both an abstract and strangely familiar construct. For the purposes of the series, it is the aforementioned media and genre transition that demands a new setting, somewhat resembling the early modern family structure. Simultaneously, the new setting must still be fully comprehensible for modern audiences. It is no surprise, then, that "modernised" versions of Shakespeare place the characters in original, not necessarily everyday circumstances. For instance, Michael Almereyda'a Hamlet is set in "Denmark Corporation", where the early modern family hierarchy is transformed into a corporate reality of CEOs and power squabbles over assets control. Peter Moffat's ShakespeaRe-Told Macbeth is set in a Glasgow restaurant. There the mythical idea of kingship is metamorphosed into the cult status of celebrity chefs. Sons of Anarchy unveil Hamlet's struggles at the backdrop of an extended family; a motorcycle club.

When early moderns spoke of their family they very often meant all members of a given household, including all those related and unrelated by marriage or blood as well as their servants (Berry \& Foyster 2007: 7). In Sons of Anarchy such is also the understanding of the club that is the family to which all loyalties are due. Sons of Anarchy rule the fictional Californian town of Charming like a royal family, albeit a criminal family. Although they are a street gang that uses its connections with Northern Ireland and the IRA to buy and sell guns in Northern California, the police and the authorities turn a blind eye on the constant turf wars with other gangs, because the club keeps hard drugs as well as dishonest corporate businessmen out of Charming. The sons literally take justice in their own hands and kill whomever they deem dangerous to their business. However, as long as the town functions properly they are a welcome piece of the social fabric. Family was the backbone of the Elizabethan and Jacobean society, while the King or Queen were a metaphorical head to the kingdom. ${ }^{8}$ Perversely, such is the structure of the motorcycle club ruling

Both Novy's and Boose's excellent articles on family relations in Shakespeare seem to follow such a line of argumentation (Novy 1981; Boose 1982).

8 Consequently, the understanding of crime is different. As Walker writes: "[ $t]$ he harm caused by crime did not stop with the community. The king's or queen's peace had been broken. The monarch was the symbolic victim of all crimes; it was he or she whom the criminal justice system ultimately avenged" (Walker 2007: 68-69). The same mechanism works in the series. In the town where SOA rule any crime that takes place is also understood as the crime against the club. 
Charming. In the Sons of Anarchy it is the President of the Club who is the King and to whom a local businessman turns when his teenage daughter falls victim to a brutal rape during a town fair. Apparently, the police are not competent enough to bring about justice and not ruthless enough to execute bloody retaliation. In this sense Sons of Anarchy present the idea of taking justice in one's own hands, while Hamlet as a revenge tragedy problematizes the idea of private revenge. However, if one follows a pattern of interpreting the club as a royal family, ruling the town, their actions are not only seen as justified but also very much desired. On the other hand, Jax's revenge on Clay is delayed for similar reasons as Hamlet's. Initially, he is not aware that his father's death was the result of foul play. Then, he is not entirely sure of Clay's guilt and finally he is wary of disturbing the power balance within the family of the club.

In seventeenth-century England "the health and security of the nation was believed to rest on the stability of family life" (Berry \& Foyster 2007: 8). As Berry and Foyster write: "[t]he belief that good order in the family depended upon the morality of its members, and that if there was disorder in the family its repercussions would be felt well beyond the walls of the family home, meant that the family was regarded as a public institution" (Berry \& Foyster 2007: 8). In Shakespeare's Hamlet the order in the state is disturbed, because the sanctity of the family had been trampled on. At the opening of the play one learns of the impending threat of invasion by Fortinbras. Soon Hamlet learns of his late father's murder by the King's brother. In Sons of Anarchy the club's warehouse, where the guns for sale are stored, is torched by a rival club while Jax's ex-wife overdoses on drugs and gives birth prematurely to their son Abel, who has a very slim chance to survive. Simultaneously Jax finds a box of old stuff in his storage unit. Among many mementos there is a journal written by his father, outlining the ideology and motivations originally inspiring John Teller (Old Hamlet) to create and develop the club. The journal becomes the voice of the dead father that literally speaks to Jax from his grave. This rouses Gemma's and Clay's suspicions as dark family secrets resurface, threatening the stability of the club and, consequently, the town. Gemma pleads with Clay: "You've got to nail Jax down. You've got to nail him hard, Clay! Whatever it takes! I don't want the ghost of John Teller poisoning him, ruining everything we've built" (S1E1). Gemma appeals to the hard and uncompromising authority of Clay, the King and foster father to Jax. In Sons of Anarchy the authority of the King and father is not built on trust or emotional proximity but rather unwavering resolve and propinquity to violence. Any qualms that a man may have should be nipped in the bud.

Interestingly enough, Claudius calls Hamlet's dark disposition "impious stubbornness" and "unmanly grief" (Hamlet, 1.2.94). Hamlet is expected to bear his loss like a man, which excludes any outward demonstrations of emotional 
distress. Such emotional coldness and reserve seems to be a characteristic element of family relations in the early modern period. Stone empathically writes: "[a]bout all that can be said with confidence on the matter of emotional relations within the sixteenth- and early seventeenth-century family at all social level is that there was a general psychological atmosphere of distance, manipulation and deference; that high mortality rates made deep relationships very imprudent; that marriages were arranged by parents and kin for economic and social reasons with minimal consultation of the children; that evidence of close bonding between parents and children is hard, but not impossible, to document; and that evidence of close affection between husband and wife is both ambiguous and rare" (Stone 1977: 117). Obviously, Stone's uncompromising claim on lack of affection in early modern families is a generalization that has been since refined by other scholars in more recent studies (e.g., Young in Family in the age of Shakespeare, 2008). However, it seems apt to say that the patriarchal system as well as a strict division of social roles across genders did not foster emotional profuseness. Such emotional reserve also characterizes SOA members. For instance, Jax does not want to visit his tiny son in hospital as he does not want to invest emotionally in the boy. He bluntly says to Gemma: "He's not going to make it ... He's going to die". Jax, though apparently a modern man, wants to keep his distance from the newly born baby and in his attitude mirrors Stone's diagnosis of early modern emotional dryness. Antonia Fraser opposes Stone's evaluation of parental affection in the seventeenth century. In response to Stone's claims she refers to Richard Napier's notebooks, in which he recorded 134 cases of "disturbing grief", following the death of an infant (Fraser 2011 loc. 1719-1724). Yet, it is worth remembering that in the early modern period women were perceived as creatures driven by emotions, rather than reason (Aughterson 2002: 417). So early modern gender expectations allowed women to mourn their dead. For a man grief is "unmanly", to quote Claudius yet again (Hamlet, 1.2.94). The reality of a motorcycle club seems to parallel early modern gender roles, as the only acceptable way for Jax to vent in the tumult of his affects is to beat, almost to death, a drug dealer who had sold the drugs to his ex-wife Wendy in a hopeless act of retaliation. So both families, Hamlet's and Jax's, require adherence to very strict visions of masculinity and femininity, in which it is a man's role to be tough and unfeeling.

In her excellent article "Shakespeare and emotional distance in the Elizabethan family", Marianne Novy takes up the ideas first proposed by Stone and critically weaves them into the fabric of Shakespearean drama. Elizabethan England is to her "a society in conflict about emotions and a constant interplay in the experience of the individual between emotions and the ideal of control ..." (Novy 1981: 318). For her "Hamlet is built around a conflict between an 
unfeeling society and a hero with strong feelings, which he tries to control ... Hamlet must live among detached, manipulative, and suspicious people, and he defends himself from them partly by trying to mask his emotional intensity with emotional distance" (Novy 1981: 320). Hamlet is disgusted by his mother's hasty marriage and by the meagre, in his opinion, personage of his uncle, the new King and yet his sense of doom and foreboding is communicated only through his lonely musings. As he says "It is not, nor it cannot come to good;/ But break, my heart, for I must hold my tongue" (Hamlet, 1.2.158-159). In Season 1 of SOA, Jax seems to be in conflict with the heritage of his tough upbringing and a softness newly discovered in his late father's journal and, metaphorically, his tiny and helpless son. This brings one to the central figures in question: Hamlet, on the one hand, and Jax, on the other. Benedict Cumberbatch, who recently very successfully portrayed Hamlet at the Barbican said in one interview that he had previously believed that in order to play Hamlet one needed to be childless (Cumberbatch as quoted by Furness 2015). Yet he took on the part of Hamlet as a first-time father to a baby boy and discovered that his new role of a father had a beneficial impact on his understanding of the play. His personal experience of becoming a father helped him to become a better Hamlet as it enabled him "to understand the complexity of the father/son relationship" (Furness 2015). This is indeed an interesting observation also in the context of Sons of Anarchy. Shakespeare's Hamlet is unmarried and childless but he feels a heavy burden of duty towards the ghost of his father. Jax becomes a father. ${ }^{9}$ His son miraculously arrives into the world when the ghost of his father John Teller starts speaking to him through his journal, thus suspending Jax between the past and the future.

Paradoxically, the ghost of John Teller does not speak of bloody revenge but rather paints a utopian vision of "something simpler... social rebellion; Harley commune" (S1E1). When Jax confronts Gemma about Teller's vision, saying it was not supposed to be an outlaw gang "running guns", she says the club was about "brotherhood... family" (S1E1). Yet the family that the club turned into is a blood-thirsty, killing machine that blurs the individuality of single members into one ever repeated word "retaliation". Though his countenance be "more in sorrow than in anger", Shakespearean old King Hamlet comes back clad in full armour, demanding revenge for "his foul and most unnatural murder" (Hamlet, 1.2.230, 1.5.28). Hamlet is then torn between the placid acceptance of emotional bareness represented by the court and bloody vengeance. There seems to be no middle ground. The ghost, ready for war, demands uncompromising toughness from a

Jax's ex-wife Wendy gives birth to Abel in S1E1. Later on when Jax rekindles his relationship with Tara (modelled on Ophelia), she gets pregnant and subsequently gives birth to a baby boy Thomas. 
man so far engrossed in intellectual pursuits. In Sons of Anarchy it seems to be the other way round, Jax's father dedicated his journal to his two sons, one of whom had died in a gang feud. John Teller was evidently gnawed by the sense of guilt and aware of his failure in stirring the club into the right direction. Jax, who has been raised by his stepfather Clay and groomed to be a ruthless gang man, is suddenly faced with a deeply reflective and philosophical image of his father, whom he had never known. John Teller had been disgusted by the violence to which the club stooped as well as burdened by a horrible realization that the prize of freedom had to be brutality. Yet Jax's past surprisingly collides with his future. His son emerges as the main motivation in his unsuccessful attempts to go back to the roots his father had in mind.

Since appropriations usually introduce more radical changes to the original text, the transformation of the childless Hamlet into Jax, the father, should not come as a big surprise. However, this most profound divergence from the Shakespearean original radically changes the motivation and behaviour patterns of Jax. It appears to introduce a new level of meaning to the story about a son avenging his dead father. Julie Sanders highlights that the "[e]ncouraged interplay between appropriations and their sources begins to emerge ... as a fundamental, even vital, aspect of the reading or spectating experience, one productive of new meaning, applications, and resource" (Sanders 2006: 32). In the case of $S O A$ this is exactly what happens because the series might be read as a commentary on modern fatherhood. Jax seems to be torn in-between his obligations to the club and to his son. Having no education and being a slave to a patriarchal model of a family headed by a single and masculine breadwinner, he cannot free himself from the only thing he can do well, which is selling guns and heading a criminal syndicate. It seems clear that, though the roles and choices women can embrace in the modern world have substantially widened, the subsequent waves of feminism have clearly left some men behind. Jax epitomizes such a man, suspended in-between the conservative outlook on male dominance and the modern appreciation of male emotionality. There is no doubt that the reality of motorcycle clubs is predominantly conservative, condoning male superiority and promoting female submissiveness. It seems, that by espousing these ideals Jax is most at odds with the modern world. However, what finally approximates him to the Shakespearean Hamlet is the fact that he fails in his obligations towards his family. It is his role of a father, and later husband, that becomes the source of Jax's tragedy. While Hamlet is incapable of mending the twisted family dynamics in time, Jax is never able to go back to the foundations his father had tried to lay for the club.

Sanders writes that "[a]ppropriations may differ in their purposes, they range from "depolitization" of the source material to taking advantage of its "political commitment" (Sanders 2006: 57). It seems that the vastness of Shakespeare's 
Hamlet enables both of these attitudes to be exploited. Hamlet has been read and interpreted as a political play on power and patrimony as well as a domestic tragedy on skewed family relations. Hamlet, as de Grazia posits, is a "dispossessed" Prince and his behaviour could be explained in this context. As she writes: “... yet irregularities - of speech, behaviour, comportment - which modern readings take as symptoms of psychic disorder were once the signature stunts and riffs of the Clown, madman, Vice, and devil: all stock figures of privation and therefore suitable role models for the dispossessed Prince" (de Grazia 2007: 5). Following this interpretation, the world of the play revolves around power and land that ended up in the wrong hands; an interpretation wrongly overlooked in modern criticism of the play. Interestingly, the appropriation of Hamlet in Sons of Anarchy offers the audience new layers of meaning that may not strike the reader of the Shakespearean original as obvious. In the series the focus is clearly shifted to the issues of patrimony and male power. These are encapsulated in the constant turf wars between rival clubs as well as the fight over control of the club between Jax and Clay. In this sense Sons of Anarchy go back to the roots of Shakespearean imagination. In the series it is not Jax's interiority that matters in itself but the goal of mending the power dynamics, broken by the dispossession. What is more, the aforementioned "political commitment" of the series may be seen in the way Sons of Anarchy inspire commentary on the ideas of manhood and fatherhood in the modern world. The patriarchal model, dating back to the early modern family structure, eventually becomes a destructive force that leads to the decay of Jax's family. In the Shakespearean original Hamlet's revenge plan that is supposed to reverse the skewed patronymic order and to reinstate the rightful head of the family to his proper position, seems to take the heaviest toll on the female characters.

For Ophelia and her film counterpart Tara family obligations stand in the way of individual choice, self-definition, and self-awareness. Ophelia is overshadowed by two stifling, patriarchal figures of her father and brother. Yet in her loyalty towards her father and brother she does exactly what would be expected of an early modern maid. As Houlbrooke writes: "[t] he family was held together not only by affection, but also by obedience to superior authority and divine commandment. Obedience to both parents and husbands was enjoined by Scripture. The family was seen as a monarchy. The authority of human fathers, indeed of all temporal rulers, rested on that of God the Father" (Houlbrooke 1984: 21). Calling Ophelia a pawn, then, is really an injustice to her as she is the perfect image of a dutiful daughter. Yet choosing duty over one's own desires is equal to emotional disintegration. Lynda Boose analysing "the nunnery scene", writes: "[w]hen Hamlet suddenly demands of Ophelia 'Where's your father?' ..., he is essentially asking her to choose, to declare just 
where her obedience and service, her love and honor, are bound. In her response, 'At home, my lord' ... she chooses: through the very words she desperately seizes on, she indicates her own inability to break away from the weighty bonds of home and father" (Boose 1982: 329). Ophelia's mixed allegiances lead to her being swept by the wave of unfolding chaos, while Polonius emerges as a typical early modern father, a notion also mentioned in passing by Novy (1981: 320). His advice to both of his children resembles guidelines one finds in very popular, among the aristocracy, "letters of advice", which praise "the exercise of self-control, outward reserve, secrecy, and even duplicity" (Stone 1977: 96). Stone quotes a Letter of Advice to a Son written by William Wentworth who warns his son by saying: "Be very careful to govern your tongue, and never speak in open places all you think..." (Wentworth, as quoted by Stone 1977: 96). Polonius practices reserve and caution in relations with others as well as teaches the same values to both Laertes and Ophelia. Unfortunately, such duplicity, when practiced against Hamlet, reveals Polonius' clumsiness and lack of intelligence, while exposing Ophelia to the actual dangers of "emotional distance", which is exclusion and vulnerability. ${ }^{10}$

Sons of Anarchy offer a reversed dynamics. Tara, Jax's love interest, used to be his high school sweetheart. Unlike in Shakespeare, where it is Hamlet who is a student in Wittenberg, in SOA Tara comes back to Charming, a young and aspiring surgeon, having spent the last ten years in a big city, investing in her education. She arrives in Charming to bury her dead father. Any overshadowing figure who could threaten her self-determination appears to be both metaphorically and literally dead. So, from the start, one is introduced to a selfsufficient, independent and very clever woman, unencumbered by any family obligations and an equal rival to Jax's cunning and ruthless mother Gemma. Her individualism and independence threaten the family of the club. Soon one learns that it was Tara who had tried to pull Jax away from crime in the past and it is her who may become a force for a positive change now. Yet, this veneer of independence and self-sufficiency turns out to be superficial. It quickly becomes clear that Tara is actually on the run from her ex-boyfriend, now an obsessive stalker. The police cannot really help her as the dangerous exboyfriend is a federal agent himself. When she is assaulted by him in her own home, she shoots him in self-defence. The wound is not mortal but, being in shock, Tara turns to Jax for help and he finishes the job. The act is no coldblooded murder but rather a crime of passion as Jax is provoked to pull the trigger. This crime becomes a rite of passage for both of them. Tara's bed, metaphorically, becomes their marriage bed when they passionately make love over the dead body of the boyfriend. At this point one may think that Tara has

10 I am borrowing the phrase "emotional distance" from Novy (1981: 316). 
very little in common with Ophelia. Unlike Ophelia, she chooses loyalty towards a man she loves. There is no figure of an authoritarian father who could police her decision, but there is a stalker boyfriend who, like Polonius, cannot really part with the woman he is bound to lose. In reality, the condition of Ophelia and Tara is similar in many respects. Tara trades the subjection to one controlling, patriarchal figure for the dependence on the whole club, whose Jax is a part of. Both women sacrifice their individual selves for the sake of their families. In Shakespeare, Hamlet accidentally kills Polonius, which leaves Ophelia utterly alone in the world. When Jax kills Tara's ex-boyfriend her fate also seems to be sealed. Tara's reliance on the club grows with every single criminal act she is entangled in. When she becomes Jax's "old lady" (a regular girlfriend in biking slang) and gives birth to his second son she becomes vulnerable, a target for anyone who wishes to hurt the club. Later on, in an aborted kidnapping attempt, her right hand gets crushed and, consequently, her medical career is over. At this point, there is no way out of the violent and brutal world of gang turf wars. On the surface, the choices and characters of Ophelia and Tara appear to be different but the respective families that both women vow their loyalty and honour to rob them of their singularity and individual self in quite a similar manner.

Until recently, both reviewers and scholars pointed out numerous drawbacks of television as a medium suitable to capture the magnitude of Shakespeare's genius. Many critics saw an unsurmountable divide between the "the exalted cultural status of Shakespeare" and the silver screen (Smith 2007: 134). However, as Emma Smith comments on the serialization of Shakespeare's chronicles in An Age of Kings: "[t]he Folio encourages the experience of reading serially, an experience in which the endings of individual plays are subordinated to the onward movement of sequential narrative" (Smith 2007: 147). Sons of Anarchy, unlike An Age of Kings, demonstrate the serialization of a single and, what is more, a canonical play by Shakespeare. Sons of Anarchy is a TV series with great intellectual and artistic potential thanks to its indebtedness to Shakespeare's great tragedy. At the same time, as an appropriation more than an adaptation of the play, the series ventures into terrains overlooked in the interpretation of Shakespeare's original such as the dispossession of the Prince and his sense of injury stemming from it. Some critics might posit that the potential of $S O A$ is squandered on the way as, with its slow progression, the series seems to focus more and more on the exuberant portrayal of violence, relentless bike chases, shootings and bomb explosions, more in line with the sensationalism of Thomas Kyd's Spanish Tragedy or Shakespeare's Titus Andronicus rather than Hamlet. As the series develops, it emerges to be a thoroughly alternative version of Hamlet, in which Jax actually manages to outwit his step-father Clay and become the King. While the beauty 
of Shakespeare's Hamlet lies in its ambiguity, the understatements of each and every character as well as its intellectual subtlety, Sons of Anarchy might strike one as crude and primitive. Nevertheless, the generic as well as medium shift opens possibilities to discuss such issues as gender expectations, visions of femininity and motherhood as well as manhood and fatherhood in the modern world. The indebtedness to the early modern family structure shows the continuity of certain expectations people still have of both women and men. The gradual disintegration of the series key characters - Jax and Tara - shows how impossible and stifling these expectations can be and how they threaten selfdetermination and self-sufficiency of an individual. It is the preoccupation with the family and the sense of duty towards it that approximate Shakespeare's Hamlet and Sons of Anarchy. In Shakespeare and the loss of Eden: The construction of family values in early modern culture Catherine Belsey questions the values of a newly emergent nuclear family, focusing on the insecurities and threats that haunted early modern family members. In the final chapter of her study she investigates Hamlet in relation to the first family of Adam, Eve, Cain, and Abel. In her view, when the late King comes back, he makes Hamlet his avenging angel and a tool in the unsettling of the new family. The author memorably asks: "[w]hatever made us think of marriage as closure, or associate the parental relationship with the promise of security?" (Belsey 1999: 173). This rhetorical question seems to be an excellent afterthought to Sons of Anarchy, which present an extreme, almost grotesque, vision of a dysfunctional family, that is more a breeding ground for sin rather than hearth and home. In both Hamlet and SOA the family slowly and gradually eats its members alive, robbing them of their singularity and right for selfdetermination.

\section{REFERENCES}

\section{PRIMARY SOURCES}

Shakespeare, William. 2006 [1603]. Hamlet. London: The Arden Shakespeare. Sons of Anarchy. Complete seasons 1-7. $20^{\text {th }}$ Century Fox. DVD.

\section{SECONDARY SOURCES}

Aughterson, Kate. 2002 [1998]. Gender and sexuality. In Kate Aughterson (ed.), The English Renaissance: An anthology of sources and documents, 417-421. London: Routledge.

Barber, Cesar L. 1980. The family in Shakespeare's development: Tragedy and sacredness. In Murray M. Schwartz \& Coppélia Kahn (eds.), Representing Shakespeare: New psychanalytic essays, 188-202. Baltimore: Johns Hopkins University Press. 
Belsey, Catherine. 1999. Shakespeare and the loss of Eden: The construction of family values in early modern culture. New York: New Brunswick.

Berry, Hellen \& Elizabeth Foyster. 2007. Introduction. In Hellen Berry \& Elizabeth Foyster (eds.), The family in early modern England, 1-17. Cambridge: Cambridge University Press.

Boose, Lynda E. 1982. The father and the bride in Shakespeare. PMLA 97(3). 325-347.

Bradley, Andrew C. 1992 [1904]. Shakespearean tragedy - Lectures on Hamlet, Othello, King Lear and Macbeth. Hong Kong: Macmillan.

Burt, Richard. 2002. To e- or not to e-? Disposing of Shlockspeare in the Age of Digital Media. In Richard Burt (ed.), Shakespeare after mass media, 1-32. New York, NY: Palgrave. DOI: 10.1007/978-1-137-09277-9_1

Dulaney, William L. 2005. A brief history of 'outlaw' motorcycle clubs. International Journal of Motorcycle Studies, November 2005.

Fraser, Antonia. 2011 [1984]. The weaker vessel: Woman's lot in seventeenth-century England. London: Phoenix Press.

Furness, Hannah. 2015. Benedict Cumberbatch: Being a father has made me a better Hamlet. The Telegraph. http://www.telegraph.co.uk/news/celebritynews/11923143/BenedictCumberbatch-being-a-father-has-made-me-a-better-Hamlet.html (accessed 27 August 2016).

Grazia, Margreta de. 2007. Hamlet without Hamlet. Cambridge: Cambridge University Press.

Henderson, Diana E. 2007. From popular entertainment to literature. In Robert Shaughnessy (ed.), The Cambridge companion to Shakespeare and popular culture. Cambridge: Cambridge University Press. DOI: 10.1017/CCOL9780521844291.002

Houlbrooke, Ralph A. 1984. The English family 1450-1700. London: Longman.

Lanier, Douglas. 2002. Shakespeare and modern popular culture. Oxford: Oxford University Press.

Macfarlane, Alan. 1978. The origins of English individualism: Some surprises. Theory and Society 6(2). 255-277. DOI: 10.1007/BF01681752

National Gang Report 2015. 2015. https://www.fbi.gov/file-repository/national-gang-report2015.pdf (accessed 28 August 2016).

Novy, Marianne. 1981. Shakespeare and emotional distance in the Elizabethan family. Theatre Journal 33(3). 316-326.

Sanders, Julie. 2006. Adaptation and appropriation. London and New York: Routledge Taylor \& Francis Group.

Smith, Emma. 2007. Shakespeare serialized: An Age of Kings. In Robert Shaughnessy (ed.), The Cambridge companion to Shakespeare and popular culture, 134-149. Cambridge: Cambridge University Press. DOI: 10.1017/CCOL9780521844291.008

Stone, Lawrence. 1977. The family, sex and marriage in England 1500-1800. New York, NY: Harper \& Row.

Walker, Garthine. 2007. Keeping it in the family: Crime and the early modern household. In Helen Berry \& Elizabeth Foyster (eds.), The family in early modern England, 67-95. Cambridge: Cambridge University Press.

Wikipedia contributors. Sons of anarchy. In Wikipedia: The Free Encyclopedia. https://en.wikipedia.org/w/index.php?title=Sons_of_Anarchy\&oldid=734977803 (accessed 26 August 2016).

Young, Bruce W. 2008. Family in the age of Shakespeare. Westport: Greenwood Publishing Group. 